\title{
Impact of Climate Change on Water Resources in Lower Niger Basin in Nigeria
}

\author{
Itolima Ologhadien \\ Department of Civil Engineering, Rivers State University, Port Harcourt, Nigeria
}

\begin{abstract}
The objective of this paper is to investigate the temporal trends of streamflow in the Lower Niger River Basin in Nigeria using Mann - Kendall (MK), Spearman' rho (SP) and Thiel - Sen (TSA) non parametric tests at 5\% of significant level. The effect of auto - correlation in the time series was eliminated using a Trend Free Pre whitening (TFPW) approach .The results obtained show negative trends in annual maximum series and both deceasing and increasing trends in annual minimum series. The estimated slopes range $-354.94 \leq \beta \leq-$ $52.62 \mathrm{~m}^{3} / \mathrm{s} /$ year and $-0.92 \leq \beta \leq 30 \mathrm{~m}^{3} / \mathrm{s} /$ year for annual maximum and minimum series respectively. Both $\mathrm{MK}$ and SP tests showed consistent performance and ability in detection of trends at $5 \%$ significant level. The negative trends in streamflow combined with simultaneous decrease in rainfall and increase in air temperature are plausible evidence of climate change. Also, positive correlation between freshwater discharge and salinity intrusion into River Niger was observed. The combined effect of streamflow reduction and salinity intrusion will impact adversely on the agricultural potentials, water quality status and vegetation of the Lower Niger River Basin. Finally, this study recommends against construction of new reservoirs as this will exacerbate the observed negative trends, leading to unsustainable development.
\end{abstract}

Keywords: Trend analysis, Climate change, Nigeria, Salinity intrusion, Mann - Kendall and Thiel - Sen Estimator.

DOI: $10.7176 /$ CER/11-4-02

Publication date:May $31^{\text {st }} 2019$

\section{Introduction}

The availability and sustainable use of water resources is crucial for development and food security as well as economic development and livelihood of any nation. The status of water resources is a direct reflection of the climate factors on the drainage basin, thus any alteration of climatic characteristics will have direct impact on water availability. The intergovernmental panel on climate change (IPCC) in her fourth assessment report has provided very strong evidence that global warming which began since 1950 , driven mainly by the buildup of greenhouse gases (GHGs) will primarily affect precipitation, temperature and potential evapotranspiration, and inter alia hydrologic extremes. Consequently, the dramatic increase in the number of people living in "severely stressed" river basins estimated to rise to two billion people in the 2050s, exacerbated problems of water pollution and human health, sea level rise, severe flooding and droughts, GDP losses etc., are symptomatic of the global climate change( Archer and Rahmstorf, 2012). The potential impacts of climate change on hydrological extremes have been a major research concern in hydrology in the last two decades across the world. Most of these studies focused primarily on trend analysis of hydro climatic variables; precipitation, temperature and evapotranspiration( e.g., Oguntunde et al., 2011; Sonali and Kumar 2013; Oguntunde and Abiodun 2013; and Aich et al., 2016). Other publications deal explicitly on trends on streamflow( e.g. XU et al.,2014; Kahya and Kalayci 2004; and da Silva et al., 2015.

In the Niger River Basin studies such as ( Otache et al., 2004; Di Baldaosarre et al., 2010; Aich et al., April 2014; Aich et al., August 2014; Amadou et al., 2015; Aich, 2015; Nka et at., 2015; Aich et al., 2015; Aich et al.,2016; and Andersson et al., 2017 ) are worthy of review. Otache et al. ( 2004) investigated streamflow processes of the Benue River and found no trend in the annual mean discharge, but observed the presence of positive change on the trend for August, January and February using a record length of 26 years $(1974-2000)$ for Makurdi hydrological station. Baldassarre et al., (2010) studied Flood Fatalities in Africa: from diagnosis to mitigation and found intensive and unplanned human settlements in flood-prone areas as main factors for the increasing flood risk. Aich et al,. ( August -2014) studied the increasing risk floods in the Niger basin in terms of analysis and attribution factors and reported that floods in the Niger Basin are climate-driven. Aich et al., ( April - 2014 ) compared the impacts of climate change on streamflow in four large African river basins: the Niger, the Upper Blue Nile, the Oubanqui and the Limpopo using SWIM (Soil and Water Integrated Model). This study reported that climate change is clearly visible for mean discharges as well as for high and low floods. Amadou et al., (2015) investigated changes to flow regime on the Niger River at Koulikoro under a changing climate, and reported a significant decrease in the mean river flow as well as shifts in the flow regime at several locations along the river Niger. Aich (2015) studied floods in the Niger River Basin in the face of Global change - analysis, attribution and projections, and found that Climate Change influence on floods generally larger compared to land use changes. Nka et al., (2015) also investigated trends in floods in West Africa: analysis based 
on 11 catchments in the regions and observed trends in flood magnitude and flood frequency time series with two main patterns - increasing ( Sahelian region) and decreasing ( Sudanian region) trend. Aich et al., (2016) analyzed the increasing number of catastrophic floods in the Niger River Basin, focusing on the relation between long term hydro-climatic variability and flood risk over the last 40 to 100 years. The time series obtained show a general consistency between the annual maximum discharge and climatic decadal pattern in West Africa regarding both trends and major change points. Anderson et al., (2017) studied the peak river flow statistics and forecasting in the Niger River Basin as a result of the growing concern of flooding in West Africa. The results of their simulation studies indicates peak discharge increase on the average of about $20 \%$, with large uncertainty.

In summary, most of the previous studies on trend analysis of flood or streamflow in the Niger Basin have focused more on the upper Niger, inland Delta and middle Niger with scanty coverage on the lower Niger River Basin. This study therefore complements previous studies by filling the existing research vacuum in the Lower Niger River Basin. In view of the economic importance of stream flow in water resources development, this study is undertaken to investigate the trend characteristics of the lower Niger River Basin with respect to global climate change. The hydrological stations studied are situated at Aboh, Baro, Idah, Lokoja and Onitsha, on the Niger while Ibi, Makurdi, Umaisha, Yola on the Benue River. The data types are annual minimum and maximum series and for data length ranging between 30 and 62 years. The data were collated from hydrological year books of National Inlands Waterways Authority, Federal Ministry of Transport, Abuja Nigeria. The minimum and maximum streamflow data were analyzed for trend with Mann-Kendall and Spearman's rho nonparametric tests.

The Mann-Kendall, Theil-Sen Estimator and Spearman's rho tests formed the main statistical tools of the study. The main findings of this study will be correlated with trend detection studies on hydro meteorological data from Nigeria ( e.g. Oguntunde et al., 2011 and 2013) and also salinity studies (NDES, 2013 ) in the estuaries of Nun and Dodo in order to underpin the cause of the observed trends. The data and study area are presented in section2; materials and methods used comprising statistical analysis, TFPW are presented in Section 3. Section 4 lists the main results according to the objectives of the study. The discussion of results and main conclusion are presented in Section 5 and 6 respectively. This study will help in the development of strategies for planning and development of water resources to mitigate the adverse effect of climate change.

\subsection{Study Area and Data Description 2.1 Study Area}

The Niger River Basin covers a total area of approximately $2,156,000 \mathrm{Km}^{2}$, about $1,270,000 \mathrm{~km}^{2}($ about $59 \%$ ) contribute to river discharge. The remainder about $886,000 \mathrm{Km}^{2}(41 \%)$ is desert area which does not generate surface runoff (Ogilvie, 2010). The Lower Niger River Basin in Nigeria has a catchment area of $575,500 \mathrm{~km}^{2}$, about 45 percent of total active Niger Basin. The rivers in Nigeria have been arranged into five drainage basins and these in turn had been demarcated into eight (8) Hydrological Areas (HAs). Each Hydrological Area (HA) has nearly uniform hydrologic characteristics in terms of rainfall, runoff, evapotranspiration (ET), and Pan Evaporation. The HAs have been used as a guide for the management of water resources developments projects. Figure 1 shows the map of Nigeria with the 9 hydrological stations clearly marked out. In terms of runoff, the available records show that River Niger recorded a decreasing trend between 1925 and 1945, with a peak runoff of $261,800 \mathrm{MCM}$ in 1955 , the highest since streamflow gauging began in 1914. The downward trend in runoff continued to a recorded minimum annual runoff of $89,800 \mathrm{MCM}$ in 1984 . Similarly a downward trend in runoff has been observed for Benue river system. The water balance in some Nigerian cities are shown in Table 1 while the climatic water balance in terms of hydrological areas (HAs) are shown in Table 2. Table 1 shows that potential ET increases Northwards, whereas rainfall increases southwards. Surplus rainfall over ET is found around Latitude $7^{\circ}$ down to the Niger Delta. Consequently, most rivers above Latitude $7^{\circ}$ are ephemeral and also under the influence of recent Sahelian drought( Sanyu and Sumiko ,1994).

\subsection{Data Description}

Annual maximum and minimum streamflow data of the 9 gauging stations were obtained from Nigerian Inland Waterways Authority (NIWA), Lokoja Nigeria. The gauge stations are situated on the River Niger and River Benue systems. The characteristic of the selected stations are given in Table 3. The stations were established in 1914, but quality data only exist during the period stated under columns 8 and 9. River Benue, the largest tributary of the Niger River in terms of discharge, meets the Niger at Lokoja, forming a confluence. The total catchment of the Benue is $338,000 \mathrm{~km}^{2}$ of which, 71 percent (about $240,000 \mathrm{~km}^{2}$ ) lies within Nigeria (Sanyu and Sumiko ,1994). Below the confluence at Lokoja, the River Niger flows southwards to Aboh, where it bifurcates into River Nun and Forcados, and finally debouches into the Nigerian Gulf of Guinea through several estuaries ( e.g. Nun and Dodo ). 


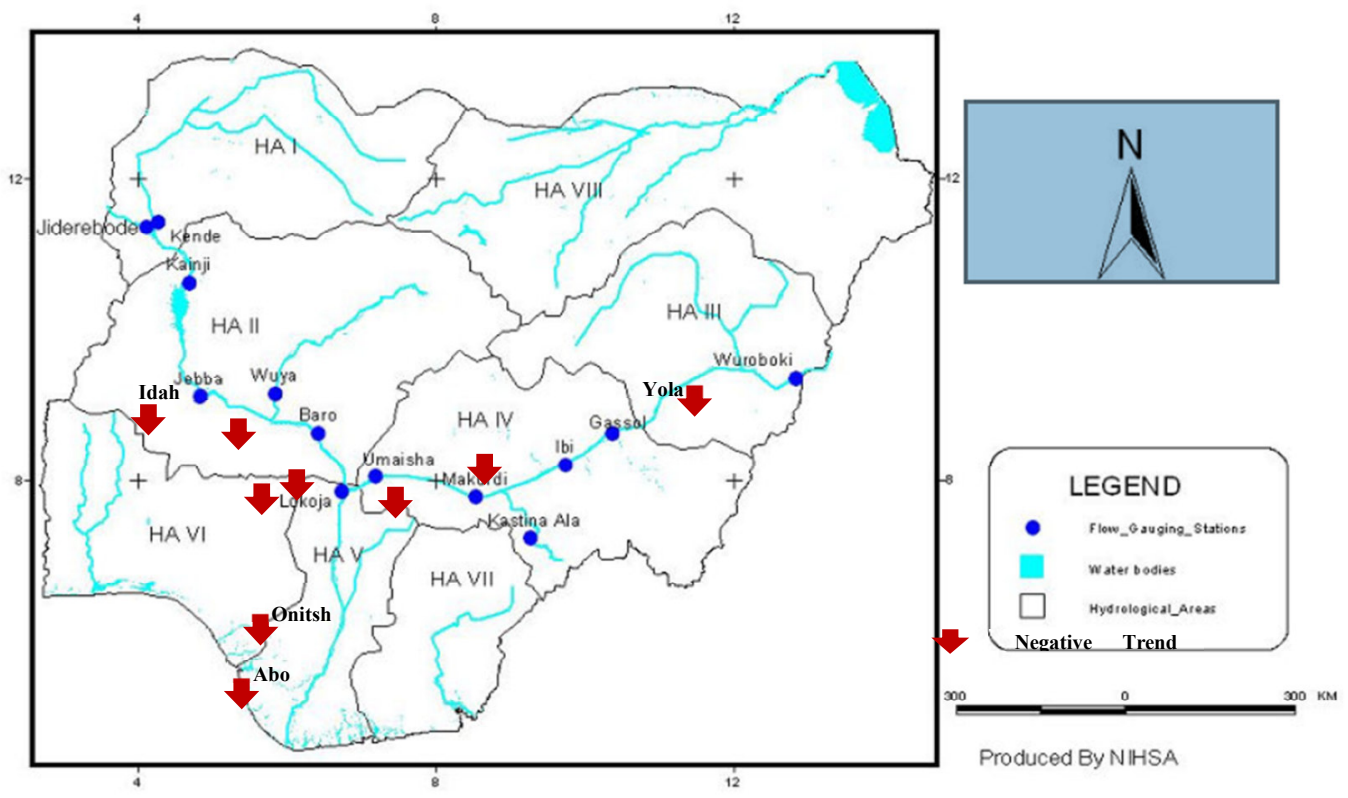

Figure 1: Showing hydrological stations with the computed trends ( in red arrows ). (Adapted from Nigerian Hydrological Services Agency(NIHSA), 2014)

Preliminary analysis, consistency and quality control checks and homogeneity tests to remove errors and detection of outliers from streamflow has been performed by an in -house Consultant engaged by NIWA.

Table 1: Water Balance in some Nigerian Cities

\begin{tabular}{llcrr}
\hline S/N & STATION & North Latitude & Mean Potential ET(mm) & Mean Rainfall (mm) \\
\hline 1 & Sokoto & $12^{\circ} 55^{\prime}$ & 2,026 & 534 \\
2 & Kano & $12^{\circ} 13^{\prime}$ & 1,815 & 713 \\
3 & Maiduguri & $10^{\circ} 51^{\prime}$ & 2,407 & 498 \\
4 & Kaduna & $10^{\circ} 41^{\prime}$ & 2,318 & 1,102 \\
5 & Bauchi & $10^{\circ} 17^{\prime}$ & 2,046 & 865 \\
6 & Minna & $09^{\circ} 39^{\prime}$ & 2,058 & 1,093 \\
7 & Jos & $09^{\circ} 38^{\prime}$ & 2,248 & 1,299 \\
8 & Yola & $09^{\circ} 14^{\prime}$ & 1,946 & 886 \\
9 & Ilorin & $08^{\circ} 29^{\prime}$ & 1,749 & 1,024 \\
10 & Makurdi & $07^{\circ} 41^{\prime}$ & 1,864 & 1,102 \\
11 & Enugu & $06^{\circ} 28^{\prime}$ & 1,724 & 1,618 \\
12 & Calabar & $04^{\circ} 58^{\prime}$ & 1,298 & 2,763 \\
\hline
\end{tabular}

There are five major reservoirs in the Niger Basin which influence the discharge regimes of the Niger and its tributaries. Three are situated in the Lower River Niger Basin namely; Kanji, Jebba, and Shiroro - and their capacities in million cubic meters (MCM) are 15,000, 3880 and 7000 respectively (Aich et el., 2014).

Table 2: Climate Water Balance over Hydrological Areas

\begin{tabular}{lrrrrrr}
\hline H $\Delta$ & Area Km & $\begin{array}{l}\text { Arial Rainfall } \\
\text { Range mm }\end{array}$ & $\begin{array}{l}\text { Mean annual } \\
\text { Pan Evap mm }\end{array}$ & $\begin{array}{l}\text { River runoff } \\
\text { MCM }\end{array}$ & $\begin{array}{l}\text { Cumm. Water } \\
\text { resources } \\
\text { Demand (MCM) }\end{array}$ & $\begin{array}{l}\text { Surplus } \\
\text { (5) - (6) } \\
\text { MCM }\end{array}$ \\
\hline I & 131,600 & 710 & 2810 & 12,100 & 3279 & 8,831 \\
II & 158,100 & 1130 & 3351 & 34,660 & 6987 & 27,673 \\
III & 158,900 & 1210 & 2100 & 49,940 & 7934 & 42,006 \\
IV & 73,000 & 1475 & 1700 & 27,810 & 4711 & 23,099 \\
V & 53,900 & 2400 & 700 & 23,690 & 2336 & 21,354 \\
VI & 100,500 & 1900 & 1650 & 35,550 & 5542 & 30,008 \\
VII & 59,800 & 1850 & 1935 & 66,080 & 5085 & 60,995 \\
VIII & 188,000 & 1600 & 4845 & 8,281 & 3105 & 5,172 \\
\hline Total & $\mathbf{9 2 3 , 0 0 0}$ & & & $\mathbf{2 5 8 , 1 2 1}$ & $\mathbf{3 8 , 9 8 3}$ & $\mathbf{2 1 9 , 1 3 8}$ \\
\hline
\end{tabular}


Table 3: Characteristics of Selected Gauge Stations

\begin{tabular}{|c|c|c|c|c|c|c|c|c|c|}
\hline $\begin{array}{l}\mathbf{1}) \\
\mathrm{S} / \mathrm{N}\end{array}$ & $\begin{array}{c}\text { (2) } \\
\text { Station }\end{array}$ & $\begin{array}{c}\text { (3) } \\
\text { Latitude } \\
\text { (N) }\end{array}$ & $\begin{array}{c}\text { (4) } \\
\text { Longitude } \\
\text { (E) }\end{array}$ & $\begin{array}{c}\text { (5) } \\
\text { River }\end{array}$ & $\begin{array}{c}\text { (6) } \\
\text { Catchment } \\
\mathrm{Km}^{2}\end{array}$ & $\begin{array}{l}\text { Annual Str } \\
\text { Max. } \\
\mathbf{m}^{3} / \mathbf{s}\end{array}$ & $\begin{array}{l}\text { eamflow } \\
\text { Min. } \\
\text { m }^{3} / \mathbf{s}\end{array}$ & $\begin{array}{c}\text { (8) } \\
\text { Period }\end{array}$ & $\begin{array}{l}\quad(9) \\
\text { Data } \\
\text { Length } \\
\text { (yrs) }\end{array}$ \\
\hline 1 & Aboh & $05^{\circ} 32^{\prime}$ & $06^{\circ} 31^{\prime}$ & Niger & $1,112,830$ & 1228.42 & 18671.41 & $\begin{array}{l}1955- \\
1989\end{array}$ & 35 \\
\hline 2 & Baro & $08^{\circ} 35^{\prime}$ & $06^{\circ} 23^{\prime}$ & Niger & 729,510 & 8852.21 & 103.45 & $\begin{array}{l}1960- \\
1989\end{array}$ & 30 \\
\hline 3 & Idah & $07^{\circ} 06^{\prime}$ & $06^{\circ} 43^{\prime}$ & Niger & $1,105,780$ & $26,760.24$ & 826.32 & $\begin{array}{l}1960- \\
1989\end{array}$ & 30 \\
\hline 4 & Lokoja & $07^{\circ} 49^{\prime}$ & $06^{\circ} 44^{\prime}$ & Niger & 750,790 & 28,360 & 248.75 & $\begin{array}{l}1955- \\
1989\end{array}$ & 62 \\
\hline 5 & Onitsha & $06^{\circ} 10^{\prime}$ & $06^{\circ} 45^{\prime}$ & Niger & $1,125,170$ & $26,607.53$ & 426.84 & $\begin{array}{l}1960- \\
2016\end{array}$ & 30 \\
\hline 6 & Ibi & $08^{\circ} 11^{\prime}$ & $09^{\circ} 45^{\prime}$ & Benue & 275,370 & $12,454.94$ & 12.68 & $\begin{array}{l}1960- \\
1989\end{array}$ & 35 \\
\hline 7 & Makurdi & $07^{\circ} 45^{\prime}$ & $08^{\circ} 32^{\prime}$ & Benue & 317,430 & $16,034.93$ & 30.48 & $\begin{array}{l}1960- \\
1989\end{array}$ & 30 \\
\hline 8 & Umaisha & $08^{\circ} 00^{\prime}$ & $07^{\circ} 14^{\prime}$ & Benue & 343,210 & $18,408.97$ & 7.71 & $\begin{array}{l}1960- \\
1989\end{array}$ & 30 \\
\hline 9 & Yola & $09^{\circ} 14^{\prime}$ & $12^{\circ} 28^{\prime}$ & Benue & 112,680 & 6641.30 & 8.93 & $\begin{array}{l}1960- \\
1984\end{array}$ & 30 \\
\hline
\end{tabular}

Extracted from Hydrological Year Books (1914 - 1989); National Inland Waterways Authority, Lokoja, Nigeria.

\section{Methodology}

\subsection{Statistical Analysis}

3.1.1 Mann-Kendall (MK) Nonparametric trend test which has been found to be an excellent statistical tool for detection of trend. The set of equations for calculating the Mann-Kendall test statistics and the standardized test statistics $Z_{\mathrm{mk}}$ are as follows:

$\sum_{i=1}^{n-1} \sum_{d=i+1}^{n} \operatorname{Sgn}\left(\mathrm{Q}_{\mathrm{j}}-\mathrm{Q}_{\mathrm{i}}\right)$

$\operatorname{Sgn}(\mathrm{Qj}-\mathrm{Qi})$ is a sign function as:

$\operatorname{Sgn}\left(\mathrm{Q}_{\mathrm{j}}-\mathrm{Q}_{\mathrm{i}}\right)=\left\{\begin{array}{l}+1 \text { if }\left(\mathrm{Q}_{\mathrm{j}}-\mathrm{Q}_{\mathrm{i}}\right)>0 \\ 0 \text { if }\left(\mathrm{Q}_{\mathrm{j}}-\mathrm{Q}_{\mathrm{i}}\right)=0 \\ -1 \text { if }\left(\mathrm{Q}_{\mathrm{j}}-\mathrm{Q}_{\mathrm{i}}\right)<0\end{array}\right\}$
$\operatorname{Var}(\mathrm{S})=$
$\frac{1}{18}\left[n(n-1)(2 n+5)-\sum_{i=1} t i\left(t_{i}-1\right)\left(2 t_{i}+5\right)\right]$

The variance is completed as:

$\mathrm{Z}_{\mathrm{mk}}=\left\{\begin{array}{c}\frac{S-1}{\sqrt{\operatorname{Var}(S)}} \text { If } \mathrm{S}>0 \\ 0 \text { if } \mathrm{S}=0 \\ \frac{S+1}{\sqrt{\operatorname{Var}(S)}} \text { if } \mathrm{S}<0\end{array}\right\}$

Where $Q_{j}$ and $Q_{i}$ are the sequential streamflow data values of the time series in the years $i$ and $j,(j>i)$ respectively, $n$ is the length of the time series, $t_{j}$ is the number of ties for the $j^{\text {th }}$ value and $q$ is the number of tied values. The summation signed $(\Sigma)$ indicates the summation over all ties values.

In the absence of tied values, the summation part of Equation 3 can be ignored. When the sample size $\mathrm{n}$ is greater than 30, the standard normal test statistics $Z_{m k}$ is computed using Equation 4. Positive value of $Z_{m k}$ indicates increasing trends, while negative values of $Z_{\mathrm{mk}}$ indicates decreasing trends in the time series. When $\left|Z_{\mathrm{mk}}\right|>Z_{1}{ }_{\alpha / 2}$, the null hypothesis is rejected and a significant trend exists in the time series. $Z_{1}-{ }_{\alpha / 2}$, is the critical value of $Z$ from the standard normal table, for $5 \%$ level of significance the value of $Z_{1}-{ }_{\alpha / 2}$, is $1.96(\mathrm{Da}$ Silva et al., 2015). 


\subsubsection{Spearman's rho (SP) test}

The Spearman's rho test like the Mann - Kendall test is a non - parametric test. The method is distribution free and has almost uniform power for linear and non-linear trends(Hamed, 2016). The Spearman's Rank statistics $\mathrm{R}_{\mathrm{sp}}$ and the standardized test statistics $\mathrm{Z}_{\mathrm{SR}}$ are:

$$
\frac{6 * \sum_{i=1}^{n}\left(R_{i}-m\right)^{2}}{n\left(n^{2}-1\right)}
$$

Where $\mathrm{n}$ is the total number of data $\mathrm{R}_{\mathrm{i}}$ is the rank of $\mathrm{m}^{\text {th }}$ observation $\mathrm{Xi}$ in the time series

$\mathrm{Z}_{\mathrm{sp}}=\mathrm{R}_{\mathrm{sp}}\left[\frac{n-2}{1-R_{s p}^{2}}\right]^{\frac{1}{2}}$

One can test the null hypothesis, $\mathrm{H}_{\mathrm{o}}: \mathrm{R}_{\mathrm{sp}}=0$ (their is not trend), against the alternate hypothesis, $\mathrm{H}_{1}: \mathrm{Rsp}<>0$ (trend exist if $R_{s p}$ is less than or greater than zero). $t_{(n-2,1-\alpha / 2)}$ is the critical value of $t$ from the t-students table, for $5 \%$ significance level.

\subsubsection{Serial autocorrelation}

The autocorrelation function is a tool to verify the independence of the time series. Given a sequence of consecutive data points, form the set of overlapping pair $\left(x_{t}, x_{t+1}\right)$ for $i=1, ., n-1$. The general approximate equation for the $\mathrm{k}^{\text {th }}$ lag is given by Equation 7. The autocorrelation function is a valuable tool for assessing different types of autocorrelation (Hamid, 2016).

$\mathrm{r}_{\mathrm{k}}=$

$$
\rho_{k}=\frac{\frac{1}{n-1} \sum_{t=1}^{n-k}\left(x_{t}-x_{t}\right)\left(x_{t+1}-x_{t}\right)}{\sum_{i=1}^{n}\left(x_{t}-x_{t}\right)^{2}}
$$

$$
x_{t}=\frac{1}{n} \sum_{t=1}^{n} x_{t}
$$

where

Where $\mathrm{x}_{\mathrm{i}}$ is an observation, $\mathrm{x}_{\mathrm{t}+1}$ is the following observation, $\mathrm{x}$ is the mean of the time series and $\mathrm{n}$ is the number of data. Based on the value of the first order autocorrelation $\left(r_{1}\right)$, the hypothesis Ho: $r_{1}$ (that there is no correlation between two consecutive observations) against the alternate hypothesis, H1: $r_{1}<>0$ defined the critical region, $u$ at the $5 \%$ level of significance as;

$$
\frac{-1-1.96 \sqrt{n-2}}{n-1} \leq r_{1} \leq \frac{-1+1.96 \sqrt{n-2}}{n-1}
$$

\subsubsection{Theil Sen Trend (TSA) Test.}

The Theil-Sen trend line is a non-parametric alternative to linear regression which can be used in conjunction with the Mann-Kendall test to estimate the magnitude of the detected trend. The Sen's method uses a linear model to estimate the slope of the trend and the variance of the residuals should be constant in time ( Da Silva et al., 2015). The Theil - Sen $\left(\mathrm{Q}_{\mathrm{ik}}\right)$ is calculated as:

$$
\mathrm{Q}_{\mathrm{ik}}=\frac{\frac{Q_{j}-Q_{k}}{j-k}}{j-k} \text { for } \mathrm{i}=1, \ldots \mathrm{n}
$$

Where $Q_{j}$ and $Q_{k}$ are the data points at time $j$ and $k(j-k)$, respectively. With a sample size of $n$, there should be a total of $\mathrm{N}=\mathrm{n}(\mathrm{n}-1) / 2$ such pairwise estimates $\mathrm{Q}_{\mathrm{ik}}$.

The Theil-Sen's Estimator of the slope is the median of the $\mathrm{N}$ values of $\mathrm{Q}_{\mathrm{ik}}$. The $\mathrm{N}$ values of $\mathrm{Q}_{\mathrm{ik}}$ are ranked in ascending order, smallest to the largest and the Sen's estimator is calculated as: 


$$
Q_{\text {med }}=\left\{\begin{array}{cl}
Q_{[(n+1) / 2]} & \text { if } n \text { is odd } \\
\frac{Q_{[n / 2]}+Q_{[(n+2) / 2]}}{2} & \text { if } n \text { is even }
\end{array}\right.
$$

The sign of $\mathrm{Q}_{\mathrm{ik}}$ reflects the data trend, while its numerical value indicates the steepness of the trend. Positive or negative slope is obtained as upward (increasing) or downward (decreasing) trend.

\subsubsection{Trend-Free Pre-Whitening - Mann - Kendall Procedure (TFPW-MK)}

The trend - free - pre - whitening procedure was applied to remove AR(1) following (Yue et al., 2002; Yue et al., 2003);

1) The slope $(\beta)$ of a trend in sample data is estimated using the approach proposed ( Theil, 1950 and Sen, 1968). The trend is assumed to be linear, and the sample data are detrended by:

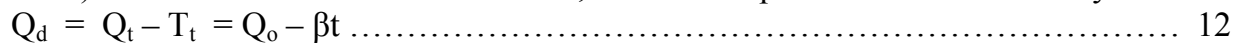

Where $Q_{d}$ is detrended time series, $Q_{o}$ is original time series, $\beta$ is slope estimated by Theil-Sen approach, $t$ is time.

2) The lag-1 serial correlation $\left(r_{1}\right)$ of the detrended time series $Q_{d}$ is computed using (Yue et al, 2002), thereafter the $\operatorname{AR}(1)$ is removed from $Q_{d}$, resulting in pre-whitened times series. $\mathrm{Q}_{\mathrm{pw}}=\mathrm{Q}_{\mathrm{d}}-\mathrm{r}_{1} * \mathrm{Q}_{\mathrm{d}-1}$

Where $\mathrm{Q}_{\mathrm{pw}}$ is pre - whitened time series, the application of Equation 13 is know as trend-free prewhitening (TFPW) procedures. The residual series after applying the TFPW procedure $\left(\mathrm{Q}_{\mathrm{pw}}\right)$ should be an independent series.

3) The identified trend $T_{t}(=\beta t)$ and Equation 13 are blended by

$\mathrm{Q}_{\mathrm{bd}}=\mathrm{Q}_{\mathrm{pw}}+\mathrm{T}_{\mathrm{t}}=\mathrm{Q}_{\mathrm{d}}-\mathrm{r}_{1} \mathrm{Q}_{\mathrm{d}-1}+\beta^{*} \mathrm{t}$.

Where $\mathrm{Q}_{\mathrm{bd}}$, is blended series, could preserve the true trend and is no longer influenced by the effect of serial correlation. In Equation 13, the trend $(\beta * \mathrm{t})$ was added back to the autocorrelation data before applying the MK test.

4) The Mann-Kendall (MK) test was therefore applied to Equation 14 to assess the significance of the trend.

\section{Results}

The main results of this study are summarized in Tables $4 \mathrm{a}$. and $4 \mathrm{~b}$., containing the descriptive statistics, auto correlation, Mann - Kendall, Spearman's rho and Thiel -Sen estimator for annual maximum and minimum series. The time series with trend lines of annual maximum streamflow are presented in Figures $2 \mathrm{a}-\mathrm{j}$ respectively. It is evidence from these graphs that all the stations exhibit long - term decreasing trends. The annual minimum series exhibit both downward and upward trends. For lack of space, their plots are not presented. The results are reported in the following order;

\subsection{Descriptive statistics}

\subsubsection{Annual maximum Series}

In column 3, Table 4a. the coefficient of variation(cv) ranges between 0.17 and 0.352 , indicating moderate to highly variable streamflow except at Aboh, Lokoja and Makurdi hydrological stations where they are less variable. In column 4, the skewness (cs) possess both positive( right skewed) and negative (left skewed), indicating a non-normal distribution. The Kurtosis coefficient $(\mathrm{Ck})$ and the excess coefficient (E) defined as $\mathrm{E}=$ $\mathrm{Ck}-3$ gave negative values in all stations, indicating a platykurtic frequency distribution more flat around its centre than a normal distribution.

\subsubsection{Descriptive statistics of Annual minimum Series}

In Table $4 \mathrm{~b}$, the $\mathrm{cv}$ values lie between 0.302 and 0.979 indicating highly variable annual minimum series . In column 4, the skewness values show asymmetrical frequency distribution with predominantly positive values. The Kurtosis $\left(C_{k}\right)$ and the excess coefficient (E) defined as $E=C_{k}-3$ also gave negative values, meaning a non normal Platykurtic frequency distribution type.

\subsection{Auto-correlation analysis.}

\subsubsection{Annual maximum series.}

The lag-1 serial correlation coefficient $\left(\mathrm{r}_{1}\right)$ with its upper class limit (UCL) and lower class limit (LCL) at 0.05 significance-level of two-tailed test for the original and TFPW data are presented in column 6 to 9 . The autocorrelation coefficient $\left(\mathrm{r}_{1}\right)$ values of the original data show that the streamflow data are serially correlated at the significance level of 0.05 . The TFPW approach was therefore applied to the original data following the sequence of steps described in sub-section 3.1.5. On application of TFPW approach, the autocorrelation coefficient $\left(r_{1}\right)$ were detrended between the LCL and UCL. The data became serially independent and fit for application of Mann-kendall and Thiel - Sen estimator methods. This study has therefore demonstrated the 
power of the TFPW approach in removing lag-one autoregressive AR(1) component.

\subsubsection{Annual minimum series.}

The results of auto - correlation analysis in columns 6 to 9 show that streamflow at Aboh, Idah, Lokoja, Onitsha, Makurdi and Umaisha are serially correlated at significant level of 0.05 . Therefore Trend-free-Pre-Whitening approach was applied to remove the effect of serial correlation on Mann-Kendall Test. The streamflow at Baro, Ibi and Yola hydrological stations are serially independent and Mann-Kendall test was applied directly to the original data.

\subsection{Trend analysis of Annual Maximum Series.}

4.3.1 The results of trend analysis using MK and SP tests and the estimation of the magnitude of the trend using TSA tests are shown in columns 10 to 13 of Table $4 \mathrm{a}$. The MK and SP tests consistently predicted significant decreasing streamflow trends in all the hydrological stations. The magnitudes of the trend detected were estimated using TSA approach and the results are shown in column 14. The range of results may be presented by the inequality; $-352.94 \mathrm{~m}^{3} / \mathrm{s} /$ year $\leq \beta \leq-52.62 \mathrm{~m}^{3} / \mathrm{s} /$ year The minimum and maximum estimated slopes in absolute terms were obtained at Onitsha and Lokoja respectively.

\subsubsection{Trend analysis of Annual Minimum Series.}

The results show significant negative trend at Aboh, Onitsha and Umaisha leading to rejection of the null hypothesis (Ho); while significant positive trend were obtained at Lokoja. Insignificant trends (negative and positive) were obtained at Baro, Idah, Ibi, Makurdi and Yola leading to acceptance of the alternative hypothesis of no trend. The results of SP and MK tests were also consistent in trend prediction. The trends identified by MK and SP tests and their respective slopes are presented in column 14. The maximum positive scope of $30 \mathrm{~m}^{3} / \mathrm{s} / \mathrm{yr}$ and the minimum negative slope of $-15.96 \mathrm{~m}^{3} / \mathrm{s} / \mathrm{yr}$ were obtained at Idah and Aboh respectively.

\subsection{Discussions}

\subsection{Trends in annual series.}

The main results indicate a decrease in annual maximum series at all the stations, and both decreasing and increasing annual minimum series. The positive trends in annual minimum streamflow in the dry season may be attributed to groundwater inflow (Ye et al., 2013). In terms of annual maximum series, the observed trends contradicts Aich et al, (2014 - April) who reported a tendency for increased streamflow for the Niger Basin however their findings, in turn contradicts the dominant water scarcity currently confronting the African subcontinent. The results on annual maximum are consistent with other research findings( e.g., Aich et al., august 2014; Aich, 2015; Nka et.al., 2015; Aich et al., 2015; Aich et al., 2016) who found general consistency between the annual maximum discharge and the prevailing climate pattern. Consequently the observed trends in streamflow are a direct response to climate change and to a lesser extend land use changes.

\subsection{Correlation of Streamflow with Meteorological Variables}

Streamflow trends are attributable to the two-main drivers of climate change and human activities such as urbanization and river regulations. In view of climate change, the main climate hazards are rainfall and temperature. Oguntunde et.al (2011) studied rainfall trends in Nigeria, $1901-2000$. Their main findings in relation to streamflow is that rainfall changes varied between -3.46 and $+0.76 \mathrm{~mm} / \mathrm{yr}$, and that about $90 \%$ of the entire landscape exhibited negative trends but only $22 \%$ showed significant changes at $5 \%$ level. Oguntunde and Abiodun (2013) studied the impact of climate change on the Niger River Basin hydroclimatology in West Africa and found elevated greenhouse gases under AIB Scenario would provide a drier climate during the raining season and a wetter climate during the dry season. Further, their model simulation suggested that between 20312050, the Niger basin climate would be warmer in all the months, and drier during the rainy months (April September). In conclusion, they showed that Nigeria landscape was generally drying since the 1970s with the driest decades between 1970 and 1990 of the $20^{\text {th }}$ century. The negative trends in rainfall and simultaneous negative trends in steamflow are plausible evidence of climate change. The results are consistent with Kahya and Kalayci (2004) who detected negative streamflow trends in Turkish rivers which were attributed to observe decrease rainfall and increase in temperature. Similarly results have been reported by Birsan et al. (2005) who studied streamflow trends in Switzerland and found a general increase in annual streamflow which was attributed to increases in winter, spring and autumn runoff. Da Silva et al. (2015) also studied the temporal and spatial variability and trends of rainfall and river flow in the Cobres River basin, southern Portugal and reported a decrease in the annual rainfall amount with simultaneously decreasing riverflow.

\subsection{Assessment of Salinity Intrusion in Nun and Dodo River Estuaries}

The longitudinal variation of salinity and maximum salinity intrusion in an estuary are important environmental concerns as they influence water utilization, agricultural development and the potential use of water resources in general ( Haddout et al., 2016 ). The intrusion length is higher during Spring tide and at dry season when the 
freshwater inflow is minimal and tidal influence is stronger ( ZHANG et al. 2010 and Yoon et al., 2013). These findings are in agreement with the Niger Delta Environmental Survey ( NDES) Report findings (ERML, 2013) for the Nigerian Gulf of Guinea ( see Figure 3 ). Thus, during the rainy season, the Influx of freshwater dilutes the brackish zone and adjacent marine waters pushing the salt wedge closer to the coastline. Consequently, the inland progression of the mangrove forest (Rhizophora racemose - saline water species) into the estuaries of Nun river and Dodo river which discharge the bulk of River Niger waters into Nigerian Gulf of Guinea, further reinforce the evidence of negative trends in streamflow. In Figure 3, the salinity intrusion lengths are lesser during the rainy season in the estuaries under the direct influence of River Niger discharge, while Table4 shows the physio - chemical properties of Nun and Dodo estuaries and their seasonal variations.

Table 4a: Results of Mann-Kendall and Spearman's Rho tests for Annual Maximum Series (AMS)

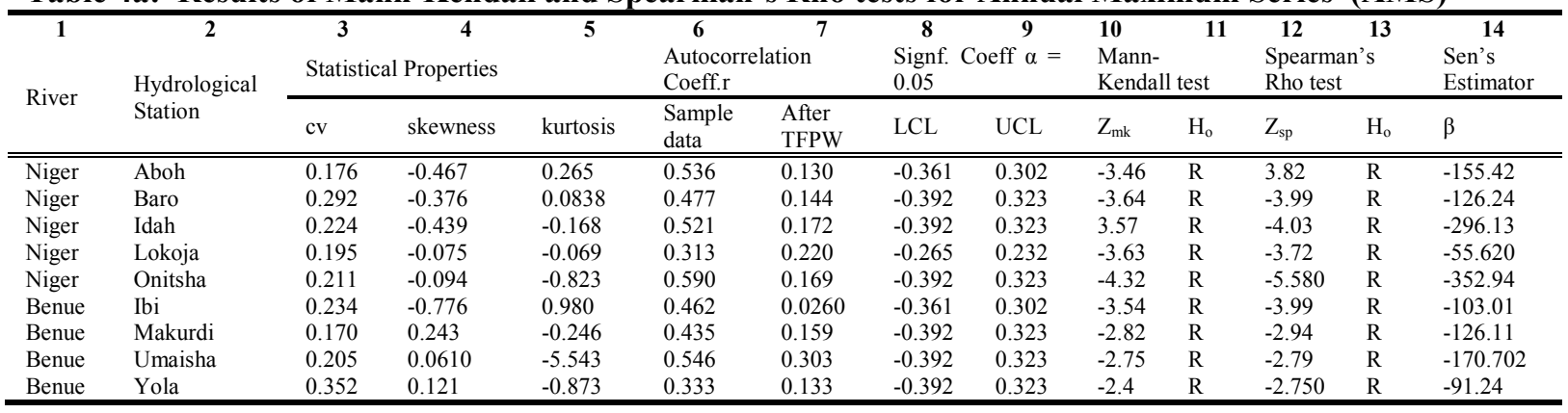

Table 4b: Results of Mann-Kendall and Spearman's Rho tests for Annual Minimum Series (AMS)

\begin{tabular}{|c|c|c|c|c|c|c|c|c|c|c|c|c|c|}
\hline 1 & 2 & 3 & 4 & 5 & 6 & 7 & 8 & 9 & 10 & 11 & 12 & 13 & 14 \\
\hline \multirow{2}{*}{ River } & \multirow{2}{*}{$\begin{array}{l}\text { Hydrological } \\
\text { Station }\end{array}$} & \multicolumn{3}{|c|}{ Statistical Properties } & \multicolumn{2}{|c|}{$\begin{array}{l}\text { Autocorrelation } \\
\text { Coefficient }(r)\end{array}$} & \multicolumn{2}{|c|}{$\begin{array}{l}\text { Signf. Coeff } \alpha= \\
0.05\end{array}$} & \multicolumn{2}{|c|}{$\begin{array}{l}\text { Mann- } \\
\text { Kendall test }\end{array}$} & \multicolumn{2}{|c|}{$\begin{array}{l}\text { Spearman's } \\
\text { Rho test }\end{array}$} & $\begin{array}{l}\text { Sen's } \\
\text { Estimator }\end{array}$ \\
\hline & & $\mathrm{cv}$ & skewness & kurtosis & $\begin{array}{l}\text { Sample } \\
\text { data } \\
\end{array}$ & $\begin{array}{l}\text { After } \\
\text { TFPW }\end{array}$ & LCL & UCL & $Z_{\mathrm{mk}}$ & $\mathrm{H}_{\mathrm{o}}$ & $Z_{\mathrm{sp}}$ & $\mathrm{H}_{\mathrm{o}}$ & $\beta$ \\
\hline Niger & Aboh & 0.380 & 0.987 & 3.28 & 0.439 & 0.149 & 0.361 & 0.302 & $\begin{array}{l}-4.15 \\
\end{array}$ & $\mathrm{R}$ & $\begin{array}{l}-4.32 \\
\end{array}$ & $\bar{R}$ & -15.96 \\
\hline Niger & Baro & 0.466 & 0.647 & 0.746 & 0.235 & NA & -0.392 & 0.323 & 0.40 & A & 0.697 & A & 2.65 \\
\hline Niger & Idah & 0.302 & 0.476 & -0.744 & 0.648 & 0.247 & -0.392 & 0.323 & 1.71 & A & 1.85 & A & 30.00 \\
\hline Niger & Lokoja & 0.353 & -0.021 & -0.636 & 0.644 & 0.133 & 0.265 & 0.232 & 2.24 & $\mathrm{R}$ & 2.58 & $\mathrm{R}$ & 12.24 \\
\hline Niger & Onitsha & 0.331 & 0.146 & -0.877 & 0.550 & 0.240 & -0.392 & 0.323 & -3.23 & $\mathrm{R}$ & -3.84 & $\mathrm{R}$ & -25.37 \\
\hline Benue & Ibi & 0.879 & 2.11 & 4.15 & 0.159 & NA & -0.361 & 0.302 & -1.30 & A & -1.56 & A & -0.92 \\
\hline Benue & Makurdi & 0.5 & 0.462 & -0.436 & 0.470 & 0.125 & -0.392 & 0.323 & -1.57 & A & -1.55 & A & -2.43 \\
\hline Benue & Umaisha & 0.621 & 0.882 & 0.586 & 0.418 & 0.183 & -0.392 & 0.323 & -2.21 & $\mathrm{R}$ & -2.47 & $\mathrm{R}$ & -4.62 \\
\hline Benue & Yola & 0.80 & 1.50 & 1.66 & 0.284 & NA & -0.392 & 0.323 & 1.43 & $\mathrm{~A}$ & 2.32 & $\mathrm{~A}$ & 0.690 \\
\hline
\end{tabular}

The number of paired data $(\mathrm{N})$ for $\mathrm{j}>\mathrm{i}$ (in Mann - Kendall analysis ): Aboh and Ibi; $\mathrm{n}=35$ years, $\mathrm{N}=595$; Baro, Idah, Onitsha, Makurdi, Umaisha and Yola, $\mathrm{n}=30$ years, $\mathrm{N}=435$; Lokoja, $\mathrm{n}=62$ years, $\mathrm{N}=1891$. 


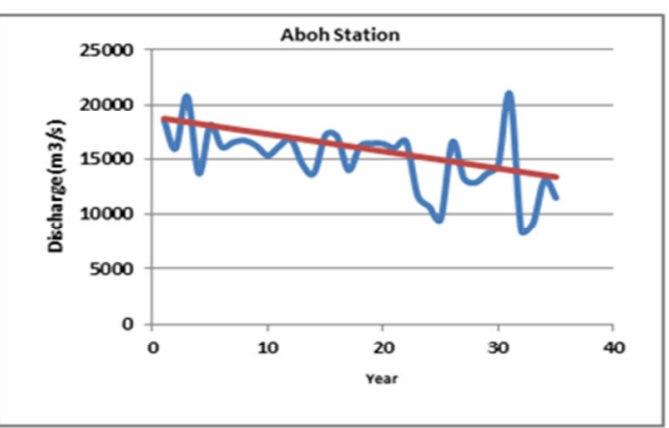

Time Series Plot of AMS With Trend Line (1955-1989)
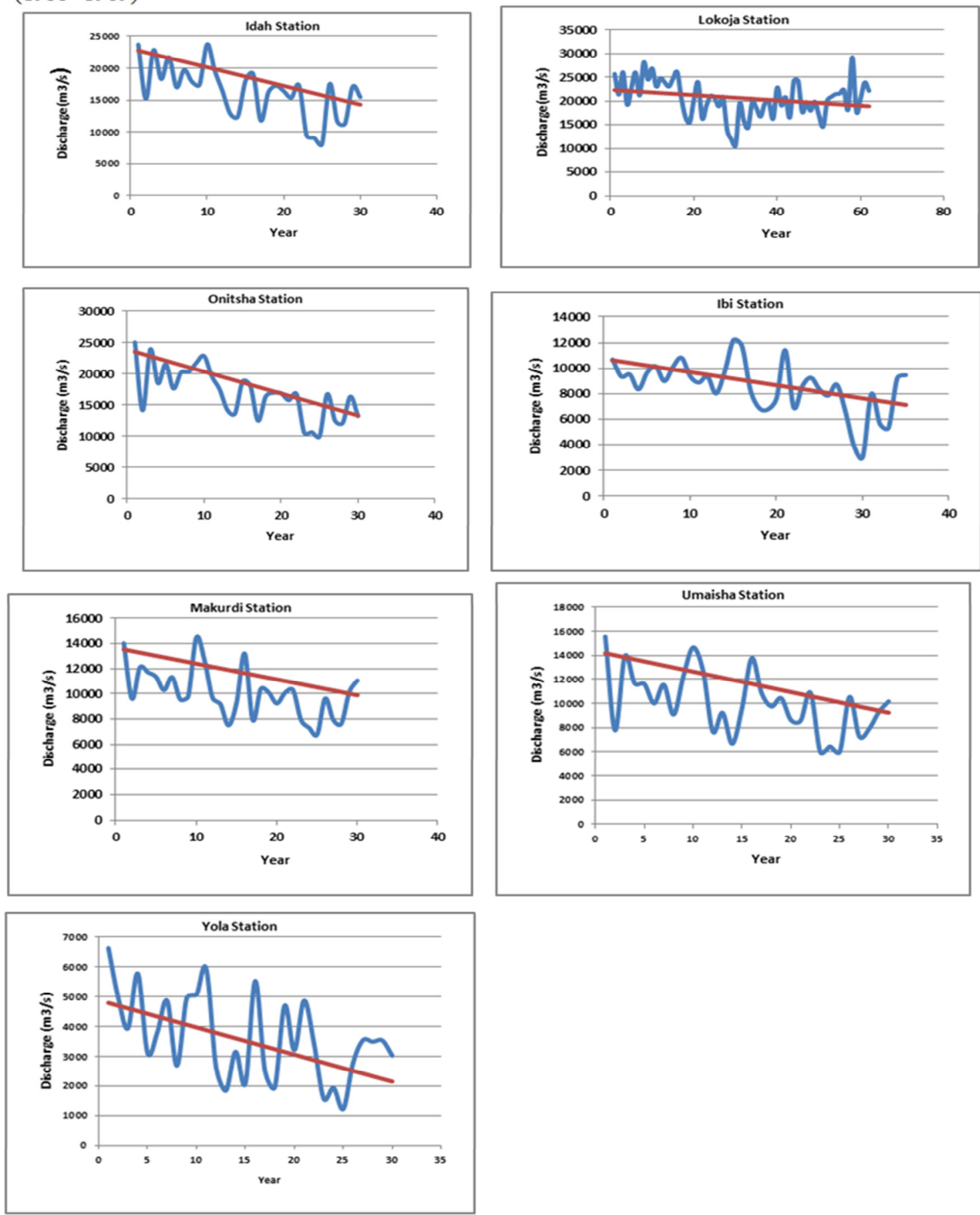

Figure 2: The trends of annual maximum series for nine hydrological stations 


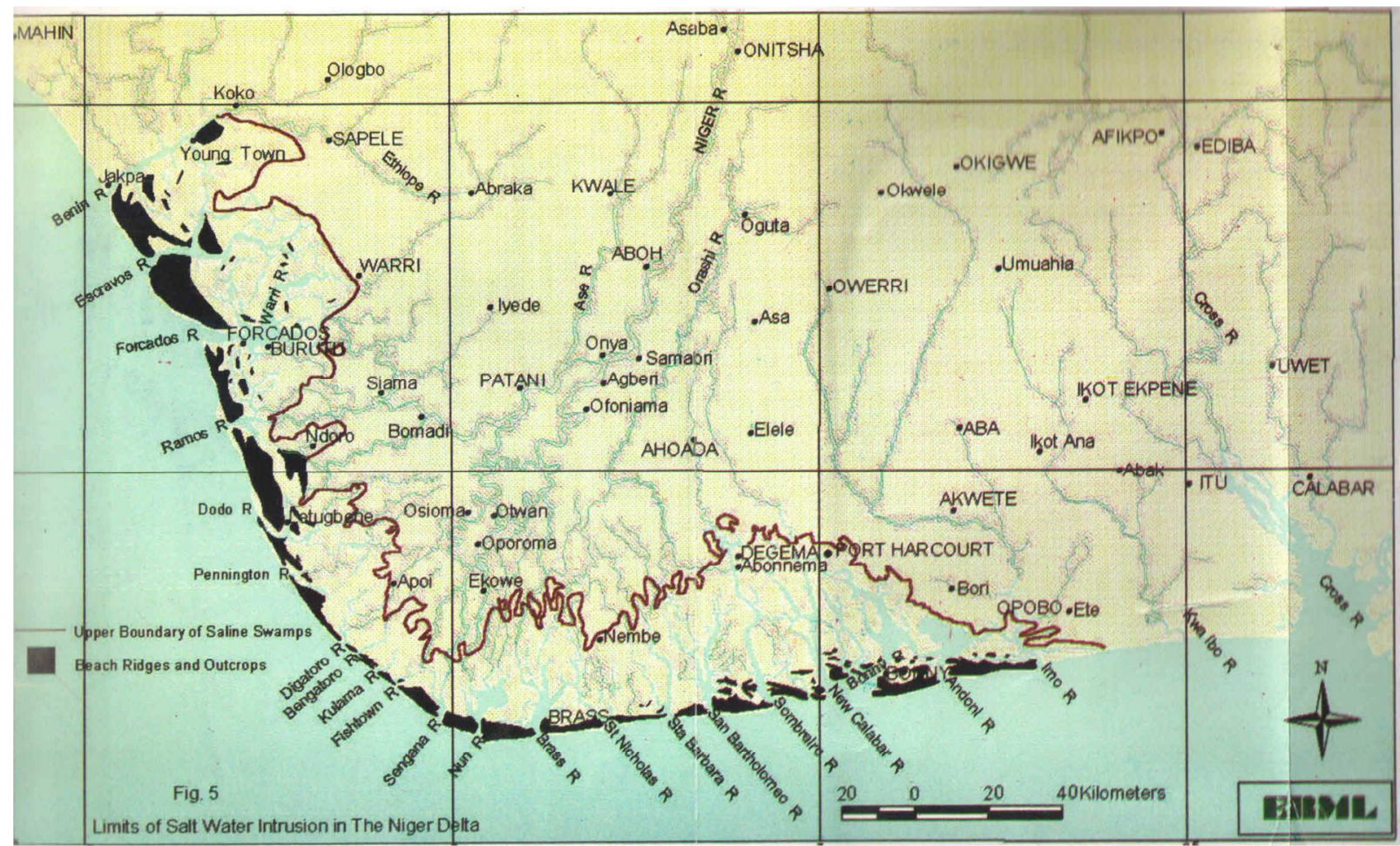

Figure 3: Salinity Intrusion in the Niger delta ( ERML/ NDES, Report 2013).

Table 4: Physico-Chemical Prosperities of River Estuaries.

\begin{tabular}{|c|c|c|c|c|c|c|c|c|c|c|c|}
\hline \multirow[t]{2}{*}{ River } & \multicolumn{3}{|c|}{ Station Charactristics } & \multicolumn{4}{|c|}{ Wet Season } & \multicolumn{4}{|c|}{ Dry Season } \\
\hline & Station & Lat. ${ }^{0} \mathbf{N}$ & $\operatorname{Long}{ }^{0} \mathbf{E}$ & $\begin{array}{l}\text { Cond. } \\
\mu S / c m\end{array}$ & $\begin{array}{l}\text { TDS } \\
\mathrm{mg} / \mathrm{l}\end{array}$ & $\begin{array}{l}\text { Sal. } \\
\% \%\end{array}$ & $\begin{array}{l}\mathrm{Cl}^{-} \\
\mathrm{mg} / \mathrm{l}\end{array}$ & $\begin{array}{l}\text { Cond. } \\
\mu S / \mathrm{cm}\end{array}$ & $\begin{array}{l}\text { TDS } \\
\mathrm{mg} / \mathrm{l}\end{array}$ & $\begin{array}{l}\text { Sal. } \\
\% \%\end{array}$ & $\begin{array}{l}\mathrm{Cl}^{-} \\
\mathrm{mg} / \mathrm{l}\end{array}$ \\
\hline \multirow{5}{*}{$\begin{array}{l}\text { River } \\
\text { Nun }\end{array}$} & Station 1 & 4.30529 & 5.07397 & 4700 & 3300 & 2.4 & 1482 & 19600 & 14000 & 11.7 & 5928 \\
\hline & Station 2 & 4.37601 & 6.14234 & 745 & 540 & 0.3 & 187.7 & 13200 & 9300 & 7.6 & 3952 \\
\hline & Station 3 & 4.65714 & 6.09256 & 62 & 70 & 0 & $<1.0$ & 79 & 60 & 0 & $<1.0$ \\
\hline & Station 4 & 4.86079 & 6.14722 & 65 & 74 & 0 & $<1.0$ & 66 & 51 & 0 & $<1.0$ \\
\hline & Station 5 & 4.95035 & 6.25794 & 63 & 70 & 0 & $<1.0$ & 61 & 47 & 0 & $<1.0$ \\
\hline \multirow{5}{*}{$\begin{array}{l}\text { River } \\
\text { Dodo }\end{array}$} & Station 1 & 4.85167 & 5.55573 & 55 & 63 & 0 & $<1.0$ & 95 & 70 & 0 & 1.9 \\
\hline & Station 2 & 4.82345 & 5.54243 & 61 & 64 & 0 & 1.0 & 9800 & 6900 & 5.4 & 2470 \\
\hline & Station 3 & 4.91224 & 5.46024 & 75 & 77 & 0 & 5.9 & 12800 & 9000 & 7.4 & 2964 \\
\hline & Station 4 & 4.83177 & 5.60484 & 59 & 65 & 0 & $<1.0$ & 6170 & 4320 & 3.2 & 1976 \\
\hline & Station 5 & 4.79985 & 5.54943 & 94 & 89 & 0 & 1.5 & 21800 & 15300 & 13.2 & 5434 \\
\hline
\end{tabular}

Sal. = salinity; Cond. $=$ conductivity, $\mathrm{TDS}=$ Total dissolve solids, $\mathrm{Cl}^{-}=$chloride ion

\subsection{Conclusion}

This study analyzed trends of streamflow data from 9 hydrological stations for plausible correlation with climate change. The main conclusions are;

1) The annual maximum series exhibited significant positive Lag-1 serial correlation at all stations, while the annual minimum series exhibited both significant positive and negative trends at Aboh, Lokoja, Onitsha, Umaisha and Yola stations. The insignificant positive and negative trends were observed at Baro, Idah, Ibi and Makurdi stations. The stations with both significant positive and negative serials correlation were pre-whitened prior to application of MK and SP tests.

2) Trend detection results using MK and SR are consistent with each other. There is an excellent agreement of performance for the two methods in the assessment of trends in annual maximum series.

3) For the annual maximum series, the maximum slope of $-55.62 \mathrm{~m} 3 / \mathrm{s} / \mathrm{yr}$ and minimum slope of $352.94 \mathrm{~m}^{3} / \mathrm{s} / \mathrm{yr}$ was estimated at Lokoja and Onitsha stations respectively. For the annual minimum series, a maximum slope of $30 \mathrm{~m}^{3} / \mathrm{s} / \mathrm{yr}$ and minimum slope of $0.92 \mathrm{~m}^{3} / \mathrm{s} / \mathrm{yr}$ were observed at Idah and Ibi stations respectively.

4) The occurrence of negative trends in streamflow with simultaneous decrease in rainfall and increase in air temperature with concomitant salinity intrusion are symptomatic of climate change. The observed inland migration of the mangrove forest ( saline water species - Rhizophora racemosa) is further 
evidence of streamflow reduction in Lower Niger River Basin and the Niger Delta.

The association between freshwater discharge and salinity intrusion require further studies in order to estimate the intrusion lengths. In view of the negative impacts of streamflow and salinity intrusion on the agricultural potentials of the Lower Niger River Basin, new upstream dams construction should be discouraged. Such developments will exacerbate the observed trends and may lead to unsustainable development similar to those reported by Yoon et at., ( 2013) for the Pearl River Delta in China.

\section{REFERENCES}

Aich, V., Liersch, S., Vetter, T., Huang, S., Tecklenburg, J., Hoffmann, P., Koch, H., Fournet, S., Krysanova, V., Mutter, E.N., \& Hattermann, F.F.( 2014) Comparing Impacts of Climate Change on Streamflow in four large African River Basins, Hydrol. Earth Sys. Sci., 18, 1305 - 1321.doi.5194/hess-18-1305-2014.

Aich, V., Liersch S., Vetter T., Andersson, J. C. M., Muller, E.N., \& Hatterman, F.F.(2015) Climate or Land use ? - Attribution of changes in River Flooding in the Sahel Zone. Water 2015, 7, 2796 - 2820 , http://dx.doi.org/ 10.3390/w7062796.

Aich, V., Kone, B., Hattermann, F.F., \& Muller, E.N. ( 2014). Floods in the Niger Basin - Analysis and Attribution. Nat. Hazards Earth Syst. Sci. Discussion; 2, 5171 - 5212, http://dx doi.org/10.5194/nhessd-25171-2014.

Aich, V., Kone, B., Hattermann, F.F., Paton, E.N.(2016). Time Series Analysis of Flood across the Niger River Basin. Water 2016, 8,165, 1-19; http://dx.doi.org/10.3390/w8040165.

Amadou, A., Djibo, A. G., Seidou. O., Sanda, I.S., \& Sittichok, K. (2015). Changes to Flow Regime on the Niger River at Koulikoro Under a Changing Climate. Hydrol. Sci. J., Vol. 60, Issue 10, 1709-1723.

Andersson, J.C.M., Ali, A., Arheimer, b., Gustafsson, D., \& Minoungou, B.( 2017). Providing peak River flow statistics and forecasting in the Niger River basin, Physics and chemistry of the earth 100(2017), 3-12.

Birsan Marius - Victor, Molnar. P., Burlando, P., \& Pfaundler, M. ( 2005). Streamflow trends in Switzerland, J. Hydrol., Elservier, doi:1016j.jhydrol 2005.06.008, 32 - 327.

Baldassarre, D.G., Montanari, A., Lins, H., Koutsoyiannis, D., Brandimarte, L., \& Bloschl, G. (2010). Flood Fatalities in Africa: From diagnosis to mitigation, Geophysical Research letters, 37, L22402, doi:10.1029/2010GL045467, 2010.

Da Silva, R. M., Santos, C. A. G., Moreira, M., Corte-Real, J., Silva, V. C.L.,\& Medeiros, I. C. ( 2015). Rainfall and River Flow Trends using Mann-Kendall and Sen's Slope Estimator Statistical Tests in Cobres Rivers Basin, Nat. Hazards (2015), 77:1205 - 1221, DOI 10.1007/s 11069-015-1644-7.

Dahmen, E.R., Hall, M. J., (1990). Screening of Hydrological Data: Tests for Stationarity and Relative consistency, Intern. Inst. for Land Reclamation and Improvement/ILRI, P. O. Box 45, 6700 AA Wageningen, The Netherlands, Publication 49.

David, A., and Stefan, R.(2012). The climate crises: An Introductory Guide to Climate Change, Cambridge University Press, ISBN 978-0-521-73255-0.

Haddout, S., Igouzal, M., \& Maslouhi, A. (2016). Analytical and Numerical study of the salinity in the Sebou river estuary (Morocco ). Effect of the Supper Blood Moon( total lunar eclipse) of 2015. Hydrol. Earth System Sciences, doi: 10.51941.

Hamed, K. H.( 2016) The distribution of Spearman's rho trend statistic for persistent hydrologic data, Hydrol. Sci. J., Vol. 61, Nos. 1 - 4, $214-223$.

Kahya, E. \& Kalayci, S.(2004). Trend Analysis of streamflow in Turkey. J. Hydrol. 289, 128 - 144.

Kendall MG ( 1975). Rank correlation methods. $4^{\text {th }}$ ed, Charles Griffin, London, 202pp.

Sanyu and Sumiko Consultants Limited. The Study on the National Water Resources Master Plan, Federal Ministry of Water Resources, Abuja, Nigeria, August 1994.

Environmental Resources Managers Limited ( ERML), Niger Delta Environmental Survey (NDES), Abridged version of Findings and Recommendations of Phase 1 Report, 1997.

Nka, B.N., Oudin, L., Karambiri, H., Paturel, J.E.,\& Ribstein, P. ( 2015). Trends in floods in west Africa: analysis based on 11 catchments in the region. Hydrol. Earth Syst. Sci., 19, $4707-4719$.

Ogilvia, A., Mahe, G., Ward, J., Serpantie, G., Lemoalle, J., Morand, P., Barbier, B., Diop, A.T., Caron, A., \& Namarra, R.(2010). Water, Agriculture and Poverty in the Niger River Basin. Water Int. 2010. 35, $594-$ 622.

Oguntunde, P. G,\& Abiodun, B. J.(2013). The Impact of Climate on the Niger River Basin Hydroclimatology, West Africa: ClimDyn(2013), 40:81-94. DOI 10.1007/s00382-012-1498-6.

Oguntunde, P.G., Abiodun, B.J.,\& Lischcia, G.(2011). Rainfall trends in Nigeria 1901 - 2000, Journal of Hydrology, 411, $207-218$.

Otache, M. Y., Bakir, M., \& Zhijia, L. (2008). Analysis of Stochastic Characteristics of the Benue River Flow Process. Chinese Journal of Oceanology and Limnology, Vol. 26 No. 2, 142 - 151, DOI:10.1007/s00343008-0142-0. 
Sen, P.K. (1968). Estimates of the regression coefficient based on Kendall's tau, J. American Statist. Assoc. 63, $1379-1389$.

Sonali, P., \& Kumar, D. N.(2013. Review of trend detection methods and their application to detect temperature changes in India. J. Hydrol. 476(2013) 212 - 227.. hpp:P//doc..org/10.1016/j.hydrol.2012.10.034.

Tao, H., Gemmer, M., Bai, Y., Su, B., \& Mao, W. ( 2011). Trends in Streamflow in the Tarim River Basin during the past 50 years: Human impacts or Climate Change? Journal of Hydrology, 400 (2011); $1-9$, doi.10.1016/j.hydrol.2011.01.016.

Theil, H. (1950). A time - invariant method of linear and polynomial regression ananysis, I, II, III, Nederl. Akad. wetensch. Proc. 53, 386 - 392; 512- 525; $1397-1412$.

Xiaqing, F., Zhang, G., \&Yin, X.( 2011). Hydrological Response to Climate Change in Nenjiang, River Basin, Northeastern China. Water Res. Management, 25:677-689, DOI.10.1007/s 11269-010-9720-y.

Xu, Z. X., Chen, Y. N., \& LI, J.Y.( 2014). Impact of climate change on Water Resources in the Tarim River Basin, Water Res. Manag. 18, Kluwer Academic Publishers, The Netherlands, 439 - 458.

Ye, X., Zhang, Q., Liu, J., Li, X.,\& Xu, C. (2013). Distinguishing the relative impacts of climate change and human activities on variation of streamflow in the Poyang lake catchment, J. Hyrol. 494 (2013) 83 - 95.

Yoon, B.I., \& Woo, S.B. (2013). Correlation between freshwater discharge and salinity intrusion in Han River Estuary, South Korea In: Conley, D.C., Masselink, G., Russel, P.E., O’ Hare, (eds.), Proceedings $12^{\text {th }}$ Int. Coastal Symposium ( Plymount, England), Journal of Coastal Research, Special Issue No.65, pp. 1247 1252, ISBN $0749-0208$.

Yue, S., Pilon, P., Phinney, B., \&Cavadias G ( 2002). The influence of auto-correlation on the ability of detect trend in Hydrological series, Hydrol. Process., 16: 1807-1829, doi:10.1002/hyp.1095.

Yue, S., Pilon, P., \& Phinney B (2003). Canadian Streamflow trend Detection: Impact of serial and crosscorrelation; Hydrological Science Journal, 48:1, 51-63, DOI: 10.1623/hysj.48.1.51.43478.

ZHANG, Z., CUI, B., ZHAO, H., FAN, X., \& ZHANG, H. ( 2010). Discharge - salinity relationship in Modaomen waterway, Pearl River estuary, Procedia environmental Sciences 2 ( 2010), pp. 1235 - 1245. 